\title{
An update on possibilities of metals recovery from Polish copper ores by biotechnology. Project Ecometals
}

\author{
Agnieszka Szubert $^{1 *}$, Anne-Gwénaëlle Guezennec ${ }^{2}$, Françoise Bodénan ${ }^{2}$,Stefan Dirlich ${ }^{3}$, Agnieszka Pawłowska ${ }^{4}$, Andrzej \\ Grotowski ${ }^{1}$, Zygmunt Sadowski ${ }^{4}$, and Kajetan Witecki ${ }^{1}$ \\ ${ }^{1}$ KGHM Cuprum Sp. z o.o. Research and Development Center, Environmental Protection and Processing Department, 53-659 Wroclaw, \\ Poland \\ ${ }^{2}$ Bureau de Recherches Géologiques et Minières - BRGM, 45060 Orléans Cedex, France \\ ${ }^{3}$ Helmholtz-Zentrum Dresden-Rossendorf, Helmholtz-Institut Freiberg für Ressourcentechnologie, 09599 Freiberg, Germany \\ ${ }^{4}$ Wrocław University of Science and Technology, Faculty of Chemistry, Department of Chemical Engineering, 50-373 Wroclaw, Poland
}

\begin{abstract}
The possibilities of metals recovery from copper ores with the biotechnological methods are widely known. The methods consist in bioleaching of copper ores, copper concentrates and byproducts of their production, as well as metals recovery from leaching solutions. Biohydrometallurgical methods were tested for years to be applied at KGHM Polska Miedź S.A., in order to improve efficiency of copper production. Several different research units worked on the topic, and the most significant and wide range initiatives in this area are mentioned in this article. One of the initiatives is an ongoing German and French Ecometals project. KGHM Polska Miedź S.A. and KGHM Cuprum Ltd. Research and Development Centre are this project Partners. In the frame of the project different metals bearing materials (ores, concentrates and tailings) are tested. Among them three lithological types of the copper ore from Rudna mine and the copper concentrate from Lubin concentrator are used for studies. The article gives a general overview of these activities, with the main focus on results of bioleaching studies of selected materials, conducted by KGHM Cuprum. In these studies sandstone and shale, as well as so called "shale concentrate" (containing $39 \%$ of the shale) were used for experiments, and possibilities of their bioleaching were evaluated.
\end{abstract}

\section{Possibilities of biohydrometallugical methods application for treatment of Polish copper ores. A state of the art}

The methods of metals recovery from copper ores with the biotechnological methods are widely known. The methods consist in bioleaching of coper ores, concentrates or by-products of the concentrates production processes, followed by metals recovery from leaching solutions.

Biohydrometallurgical methods, and especially bioleaching, were tested for years to be applied for the Polish copper ores, as well as for by-products and concentrates produced at KGHM Polska Miedź S.A., in order to improve efficiency of copper production. Several different research units have been working on the topic.

A special focus was given to ores and to the low grade concentrate from the area of the Lubin mine. At the end of the seventies, a test of an underground bacterial leaching of a sandstone ore was tried in the Lubin mine. The principle of the underground test was to leach the ore in an underground installation located in a working of the mine, without transportation on surface [1]. The principle of the underground test did not consist in leaching the rock directly into the deposit, but in its disassembling from the body of the rock and placing it in a tight, enclosed dam built in the designated ramp in the working area for that purpose. The ore in the bacterial leaching dam was immersed in a circulating bath of sulfuric acid solution, flowing from the dam to a settler. The copper ore leached at that time was mainly sandstone of $1.8 \%$ copper grade. No detailed information about the type of bacteria used is available.

In the nineties, an extensive work of possibilities of application of hydrometallurgical methods at KGHM, aiming to increase the efficiency of the mining and processing was carried out [2], considering both acidic and alkaline conditions of the process. It was not the first work which pointed out that due to the nature of Polish copper ore, the use of leaching in an acidic environment may be difficult to be justified, both from technical and economical point of view. This applies not only to the dolomitic or the shale ores, but also to the sandstone ore, in which the content of carbonate minerals is still very high. Therefore, other solutions of leaching under alkaline conditions were also analyzed. An example was a cyanide leaching which allows not only for copper, but also for silver recovery. However, because of a toxicity of this agent and necessity of its regeneration after the leaching - contrary to gold - its application was not feasible. A detailed analysis in this matter was confirmed by a concept of the leaching method of flotation tailing from

\footnotetext{
* Corresponding author: aszubert@cuprum.wroc.pl
} 
the old "Konrad" mine, elaborated at ZBiPM Cuprum [3]. As another example, an ammonia leaching was given. At the end of seventies, and then at nineteens, the ammonia leaching was proposed by the Institute of Nonferrous Metals (IMN) in Gliwice, and discussed as a method of treatment of a by-product of the copper ore flotation process at KGHM. The method allowed for copper recovery from the selected by-products, without an influence on copper recovery, but without possibility of silver recovery.

Also ferric iron leaching methods, both in a sulfuric acid and in a hydrochloric acid environment, were analysed and studied (like Clear and Cymmet methods, or the concept proposed by Wroclaw University of Technology), including bioleaching method, which was a rising technology at that time. As an interesting method, also leaching in nitric with an addition of the sulfuric acids was analysed.

Studies on possibilities of application of the hydrometallurgical and biohydrometallugical methods have been also carried out over the last fifteen years. A possibility of an application of atmospheric and pressure leaching methods for the copper concentrate processing have been investigated at the Wroclaw University of Technology with using of the copper concentrates and by-products from the Lubin concentrator (Project HYDRO supported by National Centre for Research and Development, Poland) [4].

In 2007, a three years international BIOSHALE project has been ended. It was funded by European Commisision in the frame of 6th Framework Programme. In the frame of this project, different black shale bearing raw materials were tested. As the main one, the Lubin copper concentrate was analysed to be processed by the bioleaching method [5]. The method was developed by BRGM (France) and the metals recovery $(\mathrm{Cu}, \mathrm{Ag}, \mathrm{Pb})$ method from PLS (pregnant leaching solution), by Technicas Reunidas (Spain), with cooperation of the project partners. Preliminary results indicated that after six days more than $90 \%$ of copper and more than $85 \%$ of silver can be extracted from this concentrate using a continuous stirred tank reactors technology (CSTR) [5]. The solid/liquid ratio applied in the bioleaching circuit was $15 \%$. As one of the main results of this project, a general concept of the bioleaching technology for the Lubin copper concentrate was proposed. Within this concept, the bioleaching of the Lubin concentrate in cascade of the stirred tanks bioreactor was followed by copper recovery from the leaching solution via solvent extraction and electrowinning (SX-EW), and then by hydrometallurgical silver recovery from a solid residue after the process.

The research studies on Lubin concentrate CSTR technology were continued in the next European project PROMINE, carried out in the frame of the $7^{\text {th }}$ Framework Programme of the UE. As an effect, improvements of the process in terms of S/L ratio, as well as in PLS treatment methods were proposed. The solid/liquid ratio was increased to $25 \%$ without an effect on the process efficiency after the same residence time. It was shown that after 4.7 days of a residence time of the solids in the bioreactors, the copper extraction rate reached $87 \%[6,7]$.
The increase of the $\mathrm{S} / \mathrm{L}$ ratio allowed for reducing the capacity of the bioreactors. As a result, higher copper content in the leaching solution could be obtained. This allowed for a direct use of the electrowinning process for copper recovery from the leaching solution, without necessity of application of the solvent extraction unit. A new flowsheet of the PLS treatment was proposed by Institute of Nonferrous Metals (IMN) (Gliwice, Poland) [7].

Based on the analyses of results of the abovementioned attempts, it is possible to remark that a range of tools and agents possible to be applied for leaching process did not change over the last decades. It is also difficult to update a list of the potential substrates selected at KGHM's mine-concentrator circuits of in the past years as the most perspective for application of the hydrometallurgical methods, i.e. Lubin copper concentrate, the by-products of the flotation process or the sandstone ores. Although results of the leaching tests were promising, a complex concept of the biohydrometallugical technology, including full economic analysis, of the selected materials has not been elaborated so far. As results of the biohydrometallugical projects showed the feasibility of bioleaching by autotrophic microorganism at small and pilot scale, it encourages for further studies on possibilities of application of the methods, and for studies on possibilities of application of the methods, not only for Polish copper ores but taking into account possibilities of development of prospective European deposits.

Currently, a challenging project aiming at evaluation of application possibilities of the bioleaching method for in-situ leaching of copper ores is carried out in the frame of an European BioMOre project (Horizon2020 programme) [8]. The new method has a potential to be implemented, especially for deposits which cannot be mined with traditional mining technologies because of technical and/or economic reasons. This potential will be evaluated as the final result of the project, also based on results of a pilot test, being prepared underground, in Rudna mine (KGHM Polska Miedź S.A.).

The second example of the currently ongoing project focused on application of biohydrometallurgical methods for European copper resources is the ECOMETALS project. The main challenges, current results and goals of the Ecometals project together with examples of laboratory results of bioleaching of the selected raw materials obtained from KGHM Polska Miedź S.A., are presented in this article.

\section{Ecometals project}

The Ecometals project is a German and French project, with participation of KGHM Polska Miedź S.A. and KGHM Cuprum Ltd. Research and Development Centre. In the frame of the project different metals bearing materials (ores, concentrates and mineral waste) are tested to evaluate possibilities of metals recovery with using biotechnological methods. The main focus put on the copper shale - like raw materials, originating from a sediment hosted copper deposit (known as 
Kupferschiefer), which previously was exploited in Germany. Currently the shale copper ore are mined in Poland but a potential for its exploration and their future exploitation in this area still exits. The main German areas of the deposit considered in the project were the Mansfelder Land, Spremberg and the region of Weißwasser [9]. Apart from mineral samples from Germany, the main samples tested in the project were the copper ore samples from Rudna mine (KGHM Polska Miedź S.A) and the Lubin copper concentrate.

The project is structured into six work packages and involves 17 Partners. The first three WP's deal with the identified scientific bottlenecks and case studies on primary and secondary resources. WP4 supports the three aforementioned WP's with respect to analyses, characterization of the resources as well as with the development of appropriate methodologies. WP5 aims at an integration of the processes as well as the assessment of the sustainability of the new methods proposed within the project [9].

In the frame of WP1 the above-mentioned potential areas of a future interest were characterized. Also studies on the pretreatment of the copper ores in in order to prepare potential substrates for bioleaching were carried out. The studies used traditional concentration methods (flotation) but also other methods being developed over last years, like an optical sorting of the organic rich material were applied. In WP2, a further progress in studies on efficiency and mechanisms of the bioleaching process was done. This is valuable especially in case of the bioleaching with the CSTR method, which industrial use for treatment of the copper ores is still very limited. In these terms, a multi-scale approach from molecular techniques [10] to bench-scale small pilot tests was used to demonstrate bioleaching feasibility for $\mathrm{Cu}$ recovery from the Kupferschiefer ores. Heterotrophic strains were studied by HZDR (Germany) while BRGM (France) and BGR (Germany) focused on autotrophic bacteria and optimization of operating parameters. It was shown that sparkling the bioreactors with oxygen enriched gas instead of air offers an interesting alternative process to provide an adequate oxygen supply in order to satisfy the oxygen demand, which allow operating at higher solid load [11]. Besides $\mathrm{O}_{2}$ enrichment, this study demonstrated that $\mathrm{CO}_{2}$ supplementation is required to avoid limitation of the leaching kinetics [12]. Major achievements were also carried out regarding the optimization of the temperature: temperature increase in successive bioleaching reactors improves significantly copper recovery compared to conventional bioleaching operated at constant temperature [13]. Finally, autotrophic bioleaching of the copper concentrate from Lubin concentrator was performed in an innovative pilot bioreactor $\left(2 \mathrm{~m}^{3}\right)$ at BRGM (France) (see Figure 1.) to produce pregnant leach solution (PLS) for further metal recovery testing at GEOS (Germany).

Results are currently analysed to propose an integrated concept of bio-treatment for the copper resources (WP3). Such a preliminary concept was already proposed and a first environmental evaluation of the concept was carried out by Cuprum (WP5), indicating the main environmental aspects of the process i.e. a storage of the solid waste from the process, or an energy consumption, as the major ones. This will be verified in the final evaluation of the feasibility of the process, at the end of the project.

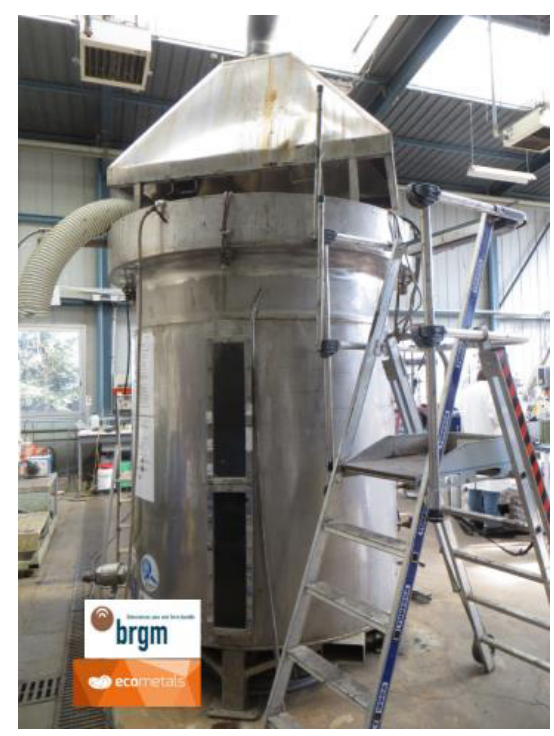

Fig. 1. $2 \mathrm{~m}^{3}$ tank for the bioleaching of the Lubin $\mathrm{Cu}$ concentrate pilot test at BRGM. Source: BRGM, France.

\section{Bioleaching experiments}

One of KGHM Cuprum's tasks in the Ecometals project consisted in bioleaching of selected copper bearing materials from KGHM. The main focus was given to a so called "shale concentrate" (containing about 39\% of shale), which was obtained from the optical sorting pilot tests of the copper ore from Rudna concentrator. This pilot test was carried out at Tomra company (Germany). The studies on possibilities of the optical sorting of the feed for the Rudna concentrator aiming in separation of the shale fraction from other lithological types of the copper ore mined at Rudna mine were planned and carried out by KGHM Cuprum within WP1.

Currently, a method of separation of the copper shale from other lithological types of the copper ore mined at KGHM does not exist. The sorting test showed that a separation of the shale material from other types of rocks is possible but the method requires further improvements to obtain a satisfying product. The idea of the separation of shale was considered as attractive because of the possibility to recover easily base and other valuable metals concentrated in this type of the ore, and because of a potential possibility of improving the enrichment factors at existing concentrator by separating this refractory type of ore from the circuit. A separation of shale ore from the feed was also supposed to separate the high organic content material from the technological circuit, and thus limiting a necessity of its removal in the smelter, prior to its processing in the flash furnaces. In addition, the separation would also limit the amount of concentrates processed in the smelter and thus reduce $\mathrm{SO}_{2}$ and dust emissions to the atmosphere. However, if a concentrate of $100 \%$ shale content is obtained from the 
sorting, none of the methods currently used at KGHM would be suitable for its further processing. Therefore, the (bio-) hydrometallurgical methods may be the only possible ones to be applied for metals recovery from this concentrate. Depending on the shale fraction, copper and valuable metals contents in the shale concentrate, two possible ways of its treatment can be considered, i.e. bioleaching with the CSTR method or on a heap. In the case of a significant silver content, like for Polish ores, a bioleaching in tank reactors seems to be more suitable, allowing for this metal recovery from the bioleaching residue. If the content of metals, which are not leachable in sulfuric acid environment is not significant, a heap leaching option could be considered. Such option is also preferred for the raw material characterized by coarse particles, which is the case for the product of the optical sorting process. Depending on characteristics of product, only a preliminary comminution of the ore can be required, for better performance of the heap (see Figure 2).

In the view of the possibility of obtaining a suitable shale concentrate in the future, examples of results of the bioleaching laboratory experiments carried out both with using the shale the mine, and with the shale concentrate, are shortly presented.

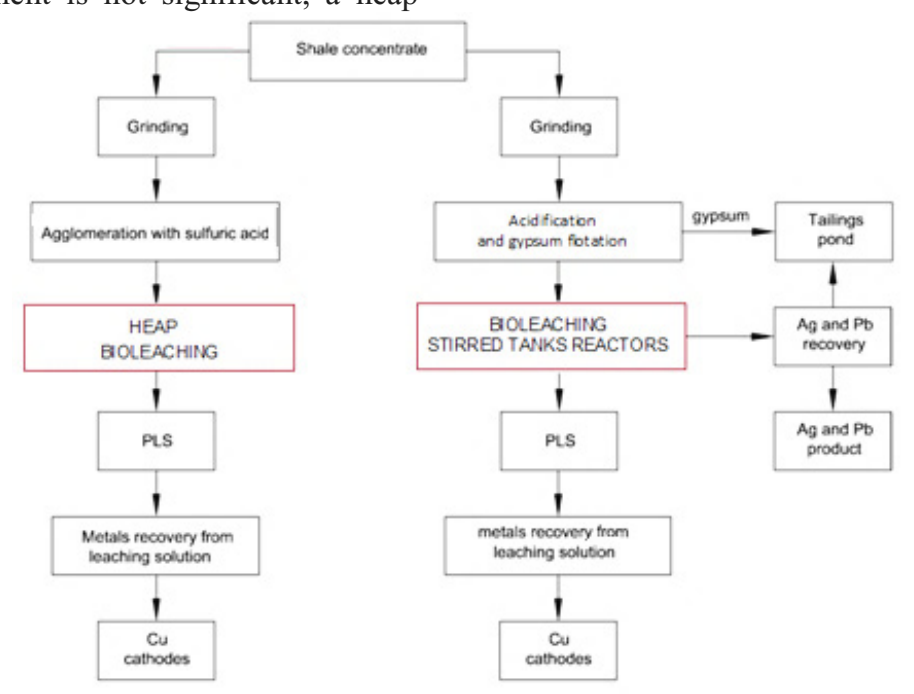

Fig. 2. Possibilities of processing of the shale concentrate.

\subsection{Bioleaching of the shale ore}

Column and bath bioleaching tests of the shale ore were carried out. The bath tests were done in $500 \mathrm{ml}$ Erlenmeyer flasks, with using ground samples, at at solid concentration of $20 \%$ (by weight). A control sample (without microorganisms) was prepared as well: in the controls, the $\mathrm{pH}$ was maintained at $<2$. The process was monitored by $\mathrm{pH}$ and redox potential measurements. Also, iron(II), iron(III) and copper(II) concentration were analyzed. For column tests the shale $(10-40 \mathrm{~mm})$ from Rudna mine was used. The content of shale used for the column test is presented in Table 1 .

Table 1. Chemical composition of the shale ore sample.

\begin{tabular}{|l|l|l|c|c|c|c|c|c|c|}
\hline $\mathbf{C u}$ & $\mathbf{C}_{\text {total }}$ & $\mathbf{C}_{\text {org }}$ & $\mathbf{F e}$ & $\mathbf{C l}$ & $\mathbf{C a O}$ & $\mathbf{M g O}$ & $\mathbf{C o}$ & $\mathbf{N i}$ & As \\
\hline \multicolumn{8}{|c|}{$\%$} \\
\hline 6.96 & 12.10 & 8.23 & 1.68 & 0.110 & 11.6 & 4.4 & 194 & 337 & 133 \\
\hline
\end{tabular}

The material was placed in a column with dimensions $10 / 60 \mathrm{~cm}$. In the first step, washing of the feed was carried out with sulfuric acid solution until a stable $\mathrm{pH}$ conditions (i.e. $<2.0$ ) were obtained. During this time, chlorides content in the solution was also checked, as too chlorides concentration is harmful for the bacteria. The solution flowrate at this stage was higher than during bioleaching $(11.3 \mathrm{l} / \mathrm{h})$. The washing of the shale was performed during
26 days. After that period the solution was partially removed from the circuit and the bacterial culture was added to the system. During bioleaching, the flow rates of the solution were smaller, to simulate an assumed flowrates applied on heaps $\left(8-121 / \mathrm{m}^{2} / \mathrm{h}\right)$ : during the last ten days of the test the flowrate was twice increased, as the wetting efficiency appeared to be too low.

The leaching solution containing microorganisms was heated $\left(37.5^{\circ} \mathrm{C}\right)$ and aerated in the collection tank, below the column. Aeration of the fixed bed in the column adapted at the beginning caused too intensive evaporation of the solution, so it was given up. During the process concentrations of chloride ions and ions of other metals (Ni, Co, As) were also measured, apart from iron, $\mathrm{pH}$ and Eh measurments.

The microorganisms used in the bioleaching experiments were obtained from the project partner: Federal Institute for Geosciences and Natural Resources (BGR), Germany. The medium for the bacteria growth contained basic mineral salts, like magnesium, sodium or ammonia sulfates, nitrate, and phosphate, small amounts of specific elements like a selected metals ions, as well as copper concentrate. After adjusting the $\mathrm{pH}$ of the solution to 2.0 the culture was maintained at $40^{\circ} \mathrm{C}$.

In the bath tests of the shale control sample, the copper recovery after 27 days was $46.0 \%$ compared to the $60.0 \%$ of the copper recovery in the samples with the presence of the bacteria. In all flasks containing bacteria, the redox 
potential increased during the process from about $400 \mathrm{mV}$ to more than $650 \mathrm{mV}$. In the control samples its value was lower than $450-500 \mathrm{mV}$.

Bioleaching of the shale in the column was carried out for a period of 95 days. For the acidification phase of the shale sample, only $200 \mathrm{ml}$ of concentrated sulfuric acid (approx. $2.5 \mathrm{~kg} / \mathrm{t}$ ) was used for neutralization of carbonates being present in the ore. Such low acid consumption indicated the reaction occurred only on the surface of the ore particles, which was proved by very low $\mathrm{MgO}$ and $\mathrm{CaO}$ leaching efficiency at the end of the process ( $17 \%$ and $4,5 \%$ respectively). Low efficiency of carbonates dissolution at the acidification stage resulted in difficulties with $\mathrm{pH}$ control in the system. This led also to local increases in $\mathrm{pH}$ in the column and consequently caused the precipitation of iron (as hydroxides or jarosite) on the surface of the shale particles. Among the precipitates, a presence of elemental sulfur was also identified in the biomass, that accumulated in the collection tank. Copper recovery was very low during such long period of time $(6.8 \%$ after acidification and $33.4 \%$ after bioleaching). It indicated that the solid has to be pre-treated before starting bioleaching in a fixed bed (column/heap), in order to deal with the rock alkalinity and gypsum issues. An efficiency of dissolution of arsenic was similar for copper whereas nickel and cobalt were not leached at all.

\subsection{Bioleaching of the shale concentrate}

The shale concentrate with low copper grade (slightly higher than $2.0 \%$ ), organic carbon content of $2.0 \%$ (which is approx. $3 \mathrm{x}$ higher than in the feed to the concentrator), and a total carbon content of $8.4 \%$. The content of other metals was similar or slightly higher than in the feed being currently directed to the concentrators. The content of the shale in this concentrate was $39.1 \%$ : unfortunately the content of dolomitic fraction in this concentrate was very high $(>50 \%)$.

The shale concentrate was ground to $-1.0 \mathrm{~mm}$ and bioleached in an aerated, single stirred tank reactor of the working volume of $7 \mathrm{~L}$, at temperature of $35^{\circ} \mathrm{C}$ and $\mathrm{S} / \mathrm{L}$ ratio of $25 \%$. The $\mathrm{pH}$ of the suspension was maintained at $1.6-1.8$. At the acidification stage $545 \mathrm{ml}(311.0 \mathrm{~kg}$ acid /ton of ore) of concentrated sulfuric acid was added to the system to get the appropriate $\mathrm{pH}$ for the bioleaching process. After acidification stage, the inoculum was introduced to the system $(10 \% \mathrm{vol})$. During the process the solution was analyzed for iron (II) and iron (III), copper (II) and if necessary, also for other metals. The $\mathrm{pH}$ and redox potential were also measured. The microorganisms used in the bioleaching experiments were obtained from the project partner, BGR (Germany), and prepared in the same way as for the tests with the shale ore.

In the bath tests with using the shale concentrate $(-1.0 \mathrm{~mm})$, the copper recovery in the control sample was $63 \%$, compared to the $83 \%$ in the samples where the bacteria were added, after 27 days. The redox potential and $\mathrm{pH}$ observations were similar for this case as for the tests with the shale ore.
It was found that the copper recovery after the acidification stage was $15 \%$, and after the addition of microbial culture, the recovery increased to almost $50 \%$ after 15 days of the experiment, and then raised to more than $90 \%$. After 41 days (96\% of cu recovery) the experiments was stopped.

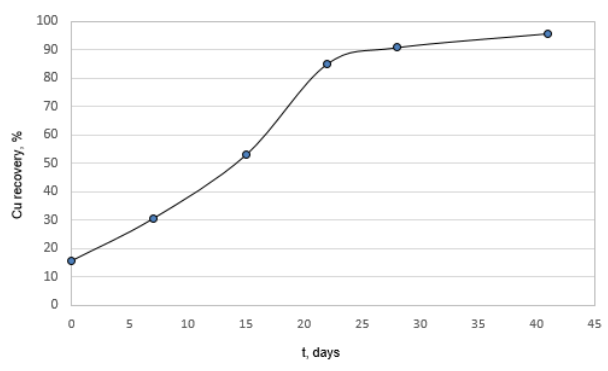

Figure 2. Bioleaching of the shale concentrate in the singe stirred tank reactor.

The bath tests experiments with the shale materials carried out in the frame of the project by Partners differed, depending on specific conditions of the process.

\section{Summary}

All the studies carried out so far indicate, the biohydrometallurgy can be an option for processing of Polish copper ores and products of their processing, as well as other European copper ores/concentrates from the sediment hosted copper deposit (of the Kupferschiefer deposit area). Justification of a future application of the method will depend on a cost-effectiveness and a technological feasibility evaluation of the treatment of a selected feed. The final results of the Ecometals project, based on data from the bioleaching pilot test of the Lublin concentrate will allow to conclude about such possibility. However the alkalinity of these rocks, as well as a high content of salts $(\mathrm{NaCl})$ remain still a challenge with regards to the processing of these raw materials with biohydrometallurgy. From this point of view, the effective, cheap and selective ways to remove the carbonates matrix from the ores prior to bioleaching need be proposed and developed.

Ecometals project is co-funded by the German Federal Ministry of Education and Research (BMBF under the Grant ID 033RF001) and the French National Research Agency (ANR13-RMNP-0006). KGHM Cuprum sp z o.o. CBR activities were co-funded by the Ecomentals project (HZDR) and internal funds of KGHM Polska Miedź S.A. The authors would like to thank to Prof. Axel Schippers and Dr. Sabrina Hedrich from the Federal Institute for Geosciences and Natural Resources (BGR), Germany, for delivery of the bacterial cultures used for the bioleaching experiments.

\section{References}

1. Zakłady Badawcze i Projektowe Miedzi (ZBPM) „Cuprum”, Projekt techniczny dołowego stanowiska prób bakteryjnego lugowania miedzi (Wrocław, 1977) 
2. A. Grotowski, Z. Sadecki, J. Lehman, M. Kalisz, W. Charewicz, T. Chmielewski et al., Rozpoznanie możliwości zastosowania niekonwencjonalnych metod pozyskiwania miedzi i innych metali w złożach o trudnych warunkach geologiczno -górniczych, report of ZBPM Cuprum sp. z o.o., in Polish, (Wrocław, 1998)

3. A. Grotowski, P. Kijewski, S. Lasko, T. Wiślicki, K. Krzysik et al., Study of Selected Problems of Reprocessing of Flotation Tailings from the no 3 Tailings Pond (Wartowice) in ZG „Konrad”, CBPM Cuprum, (Wrocław, 1995)

4. T. Chmielewski, Physicochem. Probl. Miner. Process. 51(1), 335-350 (2015)

5. P. d'Hugues, P.R Norris., K.B., Hallberg F. Sanchez, J. Langwaldt, A. Grotowski, T. Chmielewski, S. Groudev, Minerals Engineering 21, 111-120 (2008)

6. S. Kutschke, A.G. Guézennec, S. Hedrich et al., Minerals Engineering 75, 116-125 (2015)
7. A-G. Guezennec, M. Hanke., A. Chmielarz, C. Joulian, Y. Menard, P. d'Hugues, Hydrometallurgy, 10 (2014)

8. www.biomore.info

9. http:// www.ecometals.org

10. S. Hedrich, A-G Guézennec, M. Charron, A. Schippers, C. Joulian, Front. Microbiol. (2016)

11. A-G Guezennec, C. Joulian, J. Jacob, A. Archane, D. Ibarra, R. de Buyer, F. Bodénan, P. d'Hugues, Minerals Engineering 106, 64-70 (2017a)

12. A-G Guezennec, C. Joulian, J. Jacob, F. Bodénan, P. d'Hugues, S. Hedrich, Influence of $\mathrm{CO}_{2}$ supplementation on the bioleaching of a $\mathrm{Cu}$ concentrate from Kupferschiefer ore, International Bioleaching Symposium (2017b)

13. S. Hedrich, A. Schippers, C. Joulian, A-G Guezennec, Effect of temperature ramping on stirred tank bioleaching of a copper concentrate. International Bioleaching Symposium (2017) 